\title{
SHORT COMMUNICATIONS
}

\section{Distinguishing Features: Linear Rashing is Not Always Koebnerization}

\author{
Nneamaka C. Ezekwe, MD¹, Thy Huynh, MD², Robert T. Brodell, MD³ \\ ${ }^{1}$ School of Medicine, University of Mississippi Medical Center, Jackson, MS \\ 2Department of Dermatology University of Mississippi Medical Center Jackson, MS \\ ${ }^{3}$ Professor and Chair, Department of Dermatology, Professor, Department of Pathology University of Mississippi \\ Medical Center, Jackson, MS \\ ${ }^{4}$ Instructor in Dermatology, University of Rochester School of Medicine and Dentistry, Rochester NY
}

\section{INTRODUCTION}

Both cutaneous sarcoidosis and psoriasis can present with thick white scaling in a linear array. Distinguishing these conditions will alter the treatment plan.

\section{DISTINGUISHING FEATURES}

Sarcoidosis is a chronic inflammatory, multisystem disease of unknown etiology. Cutaneous involvement occurs in $25 \%$ of patients. Immunopathologically, it is characterized by a macrophage/TH1/TH17 cell-mediated, non-caseating,granulomatous inflammatory process.cutaneous sarcoidosis has a predilection for scars associated with trauma, tattoos, piercings, acne, and herpes zoster. Scar sarcoidosis produces thick, indurated, erythematous to violaceous dermal papules or nodules, and assumes the shape of linear scars. The classical presentation are well-healed flat scars that suddenly elevate, however, this can occur as early as a few months to as long as 59 years after an injury (Figure 1). ${ }^{1}$ When a cutaneous site is susceptible to infections, tumors, and immune disorders because of dysregulated local neuromodulator signaling, it can be termed an immunocompromised district. ${ }^{2}$ There may be vascular, neural, or biochemical features inherent in scars that represent fertile ground for sarcoidal granulomas to develop.

Psoriasis is a chronic autoimmune disorder associated with activated $\mathrm{T}$ cells that drive a hyperplastic, inflammatory, proliferative response through elaboration of $\mathrm{TH} 1 / \mathrm{TH} 17$ cytokines, stimulating keratinocyte to produce micaceous scaling and salmon coloration. In $25 \%$ of patients, psoriasis arises in a scratch or wound, producing raised, red linear, scaling plaques termed koebnerization (Figure 2). ${ }^{3}$ This occurs within 7 to 14 days after injury. When psoriatic lesions clear, there are often no visible scars.

Linear sarcoidosis is not the result of koebnerization as has been suggested. 4,5,6 Koebnerization occurs within days or weeks as a result of inflammation induced by trauma. Sarcoidosis occurs many months to decades after trauma in uninflamed, completely healed scars. Table 1 summarizes the features that distinguish 
Figure 1. (A) Linear sarcoidosis suddenly arising in a previously well-healed scar. (B) Linear psoriasis arising on the left posterior shoulder due to excoriation of pruritic patches. (Used with permission from the International Journal of Dermatology, volume 52. Issue 10, pages 1282-1284)

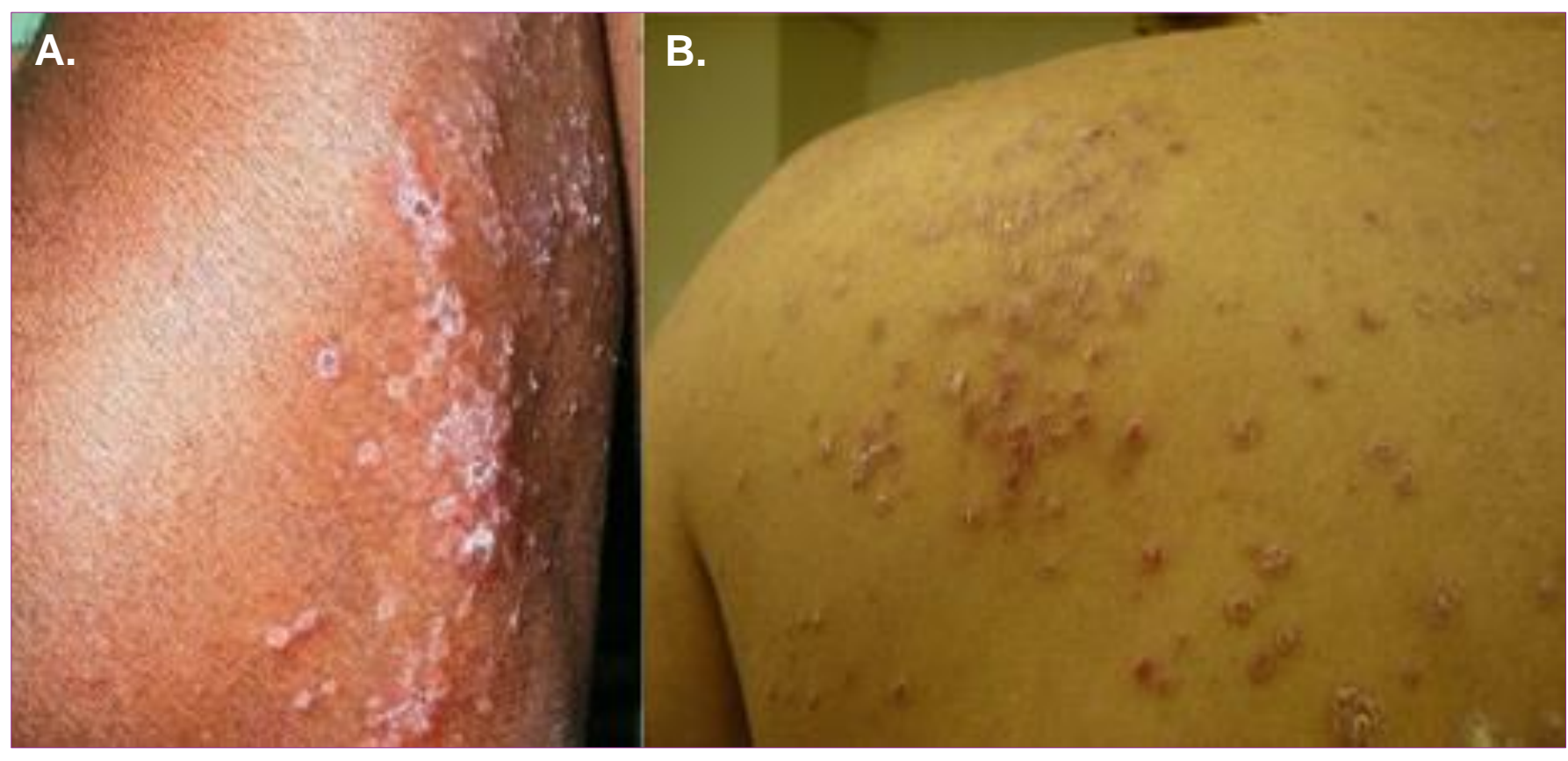

linear cutaneous sarcoidosis from linear psoriasis.

\section{EVALUATION}

Routine histological examination distinguishes cutaneous sarcoidosis from psoriasis. Sarcoidosis demonstrates islands of naked epithelioid granulomas surrounding lymphocytes and scattered multinucleated giant cells. Patients with new onset cutaneous sarcoidosis should undergo diagnostic testing (ocular examination, chest x-ray, pulmonary function tests, Kveim tests, serum ACE levels, and liver function tests) to rule out systemic involvement.

Psoriasis is largely a clinical diagnosis based on the nature and distribution of the scaling plaques. Histopathology demonstrates acanthosis, hyperkeratosis, neutrophilic spongiform pustules, and parakeratosis in the absence of serum.

\section{TREATMENT}

Cosmetically disfiguring, symptomatic, ulcerating, or progressively worsening cutaneous sarcoidosis is treated with intralesional corticosteroid therapy as firstline treatment. If local therapy fails, systemic glucocorticoids, antimalarial agents, and methotrexate are often effective. Anti-TNF biologic agents and thalidomide can be used in refractory cases (Table 1 ).

For limited plaque psoriasis arising in a scar, topical corticosteroids and emollients are first-line therapy. Alternatives include tar, topical retinoids, topical vitamin $\mathrm{D}$, and anthralin. For facial or intertriginous areas, calcineurin inhibitors are useful corticosteroid sparing agents. Intralesional steroids, systemic agents (Table 1), and phototherapy are recommended for moderate to severe psoriasis. 
Table 1: Features Distinguishing Linear Cutaneous Sarcoidosis from Linear (Koebnerized) Psoriasis

\begin{tabular}{|c|c|c|}
\hline & Psoriasis & Sarcoidosis \\
\hline Pathophysiology (General) & $\begin{array}{l}\text { TH1/TH17 cell-mediated } \\
\text { inflammatory process in the } \\
\text { region of the dermal-epidermal } \\
\text { junction }\end{array}$ & $\begin{array}{l}\text { Macrophage/TH1/TH17 cell- } \\
\text { mediated, non-caseating, } \\
\text { granulomatous infiltrate in the } \\
\text { dermis that extends into the } \\
\text { subcutaneous fat }\end{array}$ \\
\hline $\begin{array}{l}\text { Pathophysiology of } \\
\text { appearance in trauma related } \\
\text { events }\end{array}$ & $\begin{array}{l}\text { Koebnerization, an isomorphic } \\
\text { response }\end{array}$ & $\begin{array}{l}\text { Immunocompromised district, an } \\
\text { isotonic response }\end{array}$ \\
\hline $\begin{array}{l}\text { Time of onset of linear lesions } \\
\text { relative to trauma }\end{array}$ & Within 7 to 14 days after injury & $\begin{array}{l}\text { Delayed appearance } 6 \text { months } \\
\text { to } 59 \text { years after injury }\end{array}$ \\
\hline Lesion types & $\begin{array}{l}\text { Well-demarcated, raised, red } \\
\text { plaques with white scaling } \\
\text { centralized in a scar }\end{array}$ & $\begin{array}{l}\text { Thick, indurated, erythematous } \\
\text { to violaceous dermal macules, } \\
\text { papules, and solid or annular } \\
\text { plaques affecting a single color } \\
\text { in a tattoo and/or suddenly } \\
\text { appearing in well-healed scars }\end{array}$ \\
\hline Pathology & $\begin{array}{l}\text { Epidermal hyperproliferation and } \\
\text { abnormal differentiation of } \\
\text { epidermal keratinocytes with } \\
\text { chronic inflammation }\end{array}$ & $\begin{array}{l}\text { Noncaseating, chronic } \\
\text { granulomas affecting multiple } \\
\text { organs, including the skin }\end{array}$ \\
\hline $\begin{array}{l}\text { Possible associated systemic } \\
\text { involvement }\end{array}$ & $\begin{array}{l}\text { Psoriatic arthritis with joint pain } \\
\text { and metabolic syndrome }\end{array}$ & $\begin{array}{l}\text { Systemic multi-organ } \\
\text { involvement }\end{array}$ \\
\hline Treatment & $\begin{array}{l}\text { Topical/intralesional } \\
\text { corticosteroids (5-10mg/cc), } \\
\text { phototherapy, calcineurin } \\
\text { inhibitors, and systemic agents } \\
\text { including retinoids, } \\
\text { methotrexate, cyclosporine, } \\
\text { apremilast, and biologic immune } \\
\text { modifying agents }\end{array}$ & $\begin{array}{l}\text { Intralesional corticosteroids (5- } \\
10 \mathrm{mg} / \mathrm{cc}) \text {, systemic } \\
\text { glucocorticoids, antimalarial } \\
\text { agents (hydroxychloroquine and } \\
\text { chloroquine), } \\
\text { methotrexate, anti TNF agents, } \\
\text { and thalidomide }\end{array}$ \\
\hline
\end{tabular}

\section{CONCLUSION}

Cutaneous sarcoidosis and psoriasis can present with linear scaled patches. Mechanical trauma (Koebnerization) occurs in psoriasis, whereas, the linear lesions of sarcoidosis appear in well-healed scars (immunocompromised district). The distinct pathophysiologic basis of these conditions is associated with clinical and histopathologic distinguishing features.
Conflict of Interest Disclosures: Nneamaka C. Ezekwe and Thy Huynh have no conflicts of interest to report. Robert Brodell discloses the following potential conflicts of interest: Research has been performed for Glaxo Smith Kline, Novartis and Galderma laboratories. Advisory boards: Intraderm pharmaceuticals.

Funding: None

Corresponding Author:

Robert T. Brodell, MD

2500 North State Street

Department of Dermatology

Jackson, MS 39216

Phone: $601-815-8000$

Fax: 601-984-1150

Email: rbrodell@umc.edu 


\section{References:}

1. Huynh TN, Jackson JD, Brodell RT. Tattoo and vaccination sites: Possible nest for opportunistic infections, tumors, and dysimmune reactions. Clin Dermatol. 2014;32(5):678-684. doi:10.1016/j.clindermatol.2014.04.016

2. Ruocco V, Brunetti G, Puca R V., Ruocco E. The immunocompromised district: A unifying concept for lymphoedematous, herpes-infected and otherwise damaged sites. J Eur Acad Dermatology Venereol. 2009;23(12):1364-1373. doi:10.1111/j.1468-3083.2009.03345.x

3. Bhagavathula N, Nerusu KC, Fisher GJ, et al. Amphiregulin and epidermal hyperplasia: amphiregulin is required to maintain the psoriatic phenotype of human skin grafts on severe combined immunodeficient mice. Am J Pathol. 2005;166(4):1009-1016. doi:10.1016/S00029440(10)62322-X

4. Hiroaki U. Scar Sarcoidosis can be an Expression of the Isomorphic Response of Koebner against the Scar. Kawasaki Med J. 2001;27(2):67-73.

5. Ghorpade A. Sarcoidosis presenting as psoriasiform Koebnerized papules in an Indian male. Int J Dermatol. 2013;52(10):1282-1284. doi:10.1111/j.1365-4632.2011.05155.x

6. Ueki H. Koebner phenomenon in lupus erythematosus with special consideration of clinical findings. Autoimmun Rev. 2005;4(4):219223. doi:10.1016/J.AUTREV.2004.11.007 